Methods: 192 patients with BMES secondary to osteoarthritis localized to knee, hip, wrist or foot were randomly assigned to I.V. infusion of $100 \mathrm{mg}$ neridronate given four times over 10 days (Group A, 72 subjects) or alternatively to I.V. infusions of $100 \mathrm{mg}$ every 21 days over 3 months (Group B, 120 subjects). At baseline and after 180 days we performed an MRI. We assessed a $0-100 \mathrm{~mm}$ pain VAS in each patient, too. Outcomes were to evaluate the MRI changes and the VAS changes. A control group (35 patients) was enrolled too, treated conservatively with NSAIDs and articular rest. Results: we observed a significant improvement in MRI with the resolution of bone marrow lesions present at the baseline $(p<0.01)$, without a significant difference between Group A and Group B. Visual analogue scale (VAS) score decreased significantly during the study in both groups $(p<0.05)$ without a significant difference between the two treatment groups $(p>0.1)$. Both groups showed a significant clinical and radiologic improvement compared with control group $(p<0.001)$.

Conclusion: In patients with BMES, the infusions of neridronate $100 \mathrm{mg}$ every 21 days over 3 months or alternately every 3 days over 10 days are associated with clinically relevant and persistent benefits without significant differences between the two treatment-schedules. These results provide conclusive evidence that the use of bisphosphonates, at appropriate doses, is the treatment of choice BMES.

Disclosure of Interests: : None declared

DOI: 10.1136/annrheumdis-2020-eular.4353

\section{THU0464 USE OF BENZODIAZEPINES AND ANTIDEPRESSANTS IN PATIENTS WHO ATTEND A RHEUMATOLOGY CLINIC}

M. P. Martínez-Vidal ${ }^{1}$, A. Alvarez de Cienfuegos ${ }^{2}$, V. Jovani ${ }^{3}$, R. MartínDomenech $^{4}$, M. T. Pedraz-Penalva ${ }^{4}$, P. Bernabéu ${ }^{3}$, J. R. Noguera-Pons ${ }^{5}$ ${ }^{1}$ Hospital Universitario San Juan de Alicante, Alicante, Spain; ${ }^{2}$ Hospital Vega Baja, Orihuela, Spain; ${ }^{3}$ Hospital General Universitario de Alicante, Alicante, Spain; ${ }^{4}$ Hospital General Universitario de Elda, Elda, Spain; ${ }^{5}$ Hospital General Universitario de Elche, Elche, Spain

Background: During the last decades, anxiolytics and antidepressants (ADP) have been among the most prescribed therapies in all developed countries (1). In Spain a prevalence of use of $11.4 \%$ was communicated (2), slightly over the European average $(3,4)$. They have potential addiction problems and side effects. Objectives: The objective of this study was to evaluate the prevalence of anxiolytics and antidepressants among patients who attend a Rheumatology consult, as well as the indication for them.

Methods: Patients who were referred for the first time to the Rheumatology consult were included. Demographical data, reason for referral and final diagnosis were recorded. Regarding the treatment with ADP or/and benzodiazepines (BDZ), their duration and the indication for the prescription were recorded. Sample size was estimated for a $0.05 \%$ alpha risk. Descriptive, univariate and multivariate analyses (ANOVA) were performed in order to study the prevalence of these treatments, and their associations with demographical or clinical characteristics. The study was approved by the Hospital Universitario de Elche Ethics Committee. Results: 350 patients were included (women $77.1 \%$, men $22.9 \%$ ), mean age 58.1 yo. $40 \%$ were occupied and $31.4 \%$ were unemployed. The majority were married or lived with a couple $(71.4 \%)$. Most of them had been referred for musculoskeletal pain (73.4\%). More than a third (39.4\%) were on BZD and/or ADP: 107 patients were on BZD (30.6\%), 68 were on ADP (19.4\%), and $47(13.4 \%)$ were on both. The most frequent reasons for their prescription were anxiety, depression and insomnia. The final diagnosis in the clinic was a non-inflammatory condition in $53.1 \%$, and inflammatory in $18 \%$. In the univariate analyses, the use of BZD/ADP was not associated with civil status, but it was associated with female sex $(p<0.001)$, unemployment $(p<0.001)$ and non-inflammatory final diagnosis $(p<0.001)$. In the multivariate analyses, the use of BZD and/or ADP was associated with female sex $(p=0.002$ [RR 3.4, Cl 95\% 1.6-7.4]) and non-inflammatory final diagnosis, specifically fibromyalgia ( $p=0.007$ [RR 16.1, Cl 95\% 2.2-120.7]). Conclusion: The use of anxiolytics and antidepressants is frequent in the patients referred to the Rheumatology clinic, and it's associated to female sex and non-inflammatory conditions, over all fibromyalgia.

References:

[1] Lagnaoui R, Depont F, Fourrier A, Abouelfath A, Bégaud B, Verdoux H, et al. Patterns and correlates of benzodiazepine use in the French general population. Eur J Clin Pharmacol. 2004;60:523-9.

[2] Ministerio de Sanidad, Servicios Sociales e Igualdad. Secretaría de Estado de Servicios Sociales e Igualdad. Delegación del Gobierno para el Plan Nacional sobre Droga. Encuesta sobre alcohol y drogas en población general en España: EDADES 2011-2012. 2013. Disponible en: http://www.pnsd. msc.es/Categoria2/observa/pdf/EDADES2011.pdf

[3] Simó Miñana J. Utilización de medicamentos en España y en Europa. Aten Primaria. 2012; 44:335-47.

[4] Khong TP, de Vries F, Goldenberg JS, Klungel OH, Robinson NJ, Ibáñez L, Petri $\mathrm{H}$. Potential impact of benzodiazepine use on the rate of hip fractures in five large European countries and the Unite d States Calcif Tissue Int. 2012;91:24-31.
Disclosure of Interests: : None declared

DOI: 10.1136/annrheumdis-2020-eular.610

\begin{tabular}{|l|l|}
\hline THU0465 & SERUM LEVEL OF ADRENOCORTICOTROPHIC \\
HORMONE IS A CONTRIBUTING HORMONE OF \\
METABOLIC SYNDROME IN NEWLY DIAGNOSED \\
FIBROMYALGIA
\end{tabular}

T. Merza Mohammad ${ }^{1}, \mathrm{M}$. Alnimer ${ }^{2} .{ }^{1}$ Hawler Medical University, College of Pharmacy, Erbil, Iraq; ' Ja'affar Sadiq University, Bagdad, Iraq, Baghdad, Iraq

Background: Evidence of components of metabolic syndrome including. Obesity dyslipidemia, abnormal glucose tolerance rate and hypertension are associated with fibromyalgia. Adrenocorticotrophic hormone (ACTH) is reported to be significantly higher in fibromyalgia patients, and it causes obesity, high blood pressure. Objectives: This study aimed to assess the serum level of ACTH as a contributing as well as a discriminator hormone in newly diagnosed fibromyalgia women presented with variable components of metabolic syndrome.

Methods: This cross-sectional study comprised 100 women with newly diagnosis fibromyalgia and 30 apparent healthy women served as control from Kurdistan region-Iraq. Clinical data including the score of fibromyalgia impact questionnaire-revised (FIQR), tender point, body mass index, waist circumference, blood pressure and fasting serum levels of glucose and lipid profile, and ACTH level. The score of metabolic syndrome was calculated using the formula:

$$
\begin{aligned}
& \frac{2 \times \text { waist }}{\text { height }}+\frac{\text { serumglucose }}{5.6}+\frac{\text { Serumtriglyceride }}{1.7} \\
& +\frac{\text { Systolic blood pressure }}{130}-\frac{\text { serum highdensity lipoprotein }}{1.02 \text { or } 1.28 \text { (maleor female) }}
\end{aligned}
$$

Results: Compared to the controls, the Fibromyalgia women displayed significantly higher values of waist circumference $(88.9 \pm 5.7 \mathrm{~cm}$ versus $87.1 \pm$ $2.7 \mathrm{~cm}, \mathrm{p}=0.019)$, systolic blood pressure $(136.1 \pm 13.5 \mathrm{mmHg}$ versus $131.4 \pm 7.1$ $\mathrm{p}=0.014)$, metabolic syndrome score $(3.10 \pm 0.25$ versus $3.03 \pm 0.19, p=0.039)$, and serum ACTH levels $(16.66 \pm 3.23 \mathrm{pg} / \mathrm{ml}$ versus $14.42 \pm 2.18 \mathrm{pg} / \mathrm{ml} . \mathrm{p}<0.001)$ Serum ACTH levels significantly and inversely correlated with the total score of the FIQR $(r=-0.320 . p=0.001)$ and number of tender points $(r=-0.374, p<0.001)$ Metabolic syndrome score is significantly and inversely correlated with the total FIQR score $(r=-0.296, p=0.003)$. Multivariable regression analysis using showed that serum level of ACTH is a significant ( $p=$ predictor of $19.7 \%$ of fibromyalgia patients (Figure 1$)$, and it is a significant $(p=0.007)$ discriminator of tender points as the area under the curve is $0.325\left(_{95 \%}\right.$ C.I.: $0.212-0.438$ ) (Figure 2).

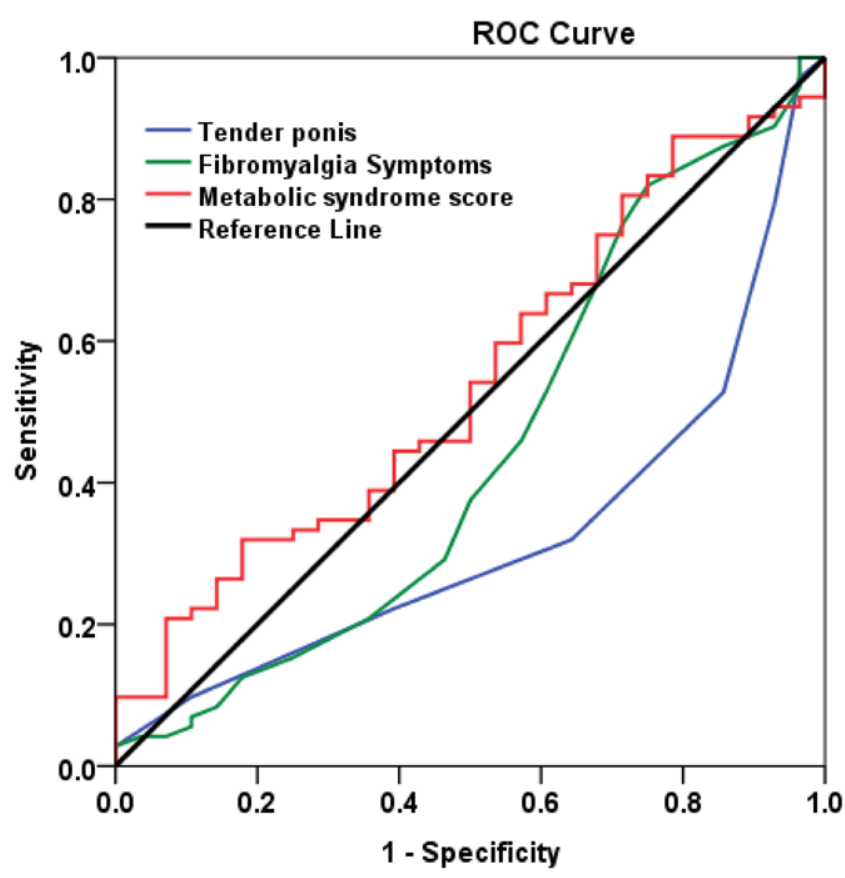

Diagonal segments are produced by ties.

Figure 2. serum level of ACTH (cutoff level $\geq 14.5 \mathrm{pg} / \mathrm{ml}$, sensitivity $=72 \%$, specificity $=50 \%$ ) as a discriminator of the tender points (AUC ${ }_{95 \%} \mathrm{C.I}^{:}: 0.325[0.212-0.438], p=0.007$ ), score of 